\title{
The Impact of Racially Disproportionate Outcomes on Public Policy: The U.S. Senate and the Death Penalty
}

\author{
CHRISTOPHER DENNIS* \\ MARSHALL H. MEDOFF \\ California State University, Long Beach \\ MICHELE N. GAGNIER \\ University of Houston
}

\begin{abstract}
The implementation of particular public policies may infringe upon important civil rights of citizens. This article explores the relationship between the racially disproportionate effects of the death penalty and a subsequent attempt in the U.S. Senate to provide racial justice protection. While the most important explanatory factors of a senator's behavior are their political philosophy and the state homicide rate the findings also indicate that racially disproportionate outcomes under capital punishment in the senator's state are negatively associated with the probability that the senator will support racial justice protection. We discuss the importance of these findings.
\end{abstract}

Regardless of the intention of policymakers, public policies sometimes have unequal effects on citizens of different races. A public policy that has racially disproportionate effects may deprive some citizens of fundamental civil rights. The purpose of this paper is to examine the impact of racially disproportionate outcomes from a public policy upon policymakers subsequent willingness to change that policy in order to minimize racially disproportionate outcomes. The Omnibus Crime Act of 1991

*Direct all correspondence to: Christopher Dennis, Department of Political Science, California State University, Long Beach, Long Beach, CA 90840-4605. Telephone: (562) 985-4711.

The Social Science Journal, Volume 35, Number 2, pages 169-181.

Copyright $\odot 1998$ by JAI Press Inc.

All rights of reproduction in any form reserved. ISSN: 0362-3319. 
provides an excellent opportunity to examine this topic. This legislation contained a "racial justice provision" that would have allowed death row inmates to challenge their sentence if they could show statistically that people of their race and within their jurisdiction were more likely to be charged with murder or sentenced to die (Biskupic, 1991).

An amendment was offered by Senator Graham (D-Florida) to strike the racial justice provision of the Omnibus Crime Act of 1991 (Congressional Record 1991, S 8300). Since the Graham Amendment focuses exclusively on redressing racially disproportionate outcomes under capital punishment, it offers an excellent opportunity to assess the impact of the degree of racially disproportionate effects of the death penalty in the senator's state on the senator's subsequent willingness to avert such outcomes. This research is an important step in understanding the impact of racially disproportionate outcomes on the formulation of public policy.

\section{Hypotheses}

The congressional voting literature suggests that both constituency characteristics and personal political orientation are likely to be related to the probability that senators will support the racial justice provision of the Omnibus Crime Act of 1991 (Bernstein, 1989; Clausen, 1973; Poole and Daniels, 1985; Smith, 1981).

\section{Constituency Characteristics}

The extent to which racially disproportionate outcomes under capital punishment occur in the senator's state could be an important factor influencing her/his vote. Intuitively we might hypothesize that the more serious a problem, the more we would favor action to eliminate it. Thus, the most straightforward expectation might be that the greater the racially disproportionate outcomes under capital punishment in the senator's state, the greater the likelihood the senator would support setting aside the death sentence for members of a race that is disproportionately affected. While such an expectation may be straightforward, the opposite relationship may be even more probable. The greater the disproportionate impact of capital punishment in the senator's state, the less likely the senator would be to favor setting aside the death sentence for members of a race that is disproportionately affected. This "negative" relationship between disproportionate outcomes and willingness to avert such outcomes might occur for two reasons. First, the greater the degree of racially disproportionate outcomes under capital punishment, the more "costly" the elimination of such outcomes. Thus, a state with highly disproportionate outcomes would face a much more difficult "adjustment" process (i.e., converting death sentences to life imprisonment) than would a state with less racially disproportionate outcomes. Therefore, senators whose states face the greatest burdens in complying with legislation to eliminate disproportionate outcomes might be expected to be the least supportive of it. Second, greatly disproportionate outcomes under capital punishment may signal that public opinion has become highly prioritized in favor of methods the electorate perceives will reduce crime with, correspondingly, less regard to violations of civil rights or liberties which may result. Therefore, we hypothesize that: 
H1. The level of racially disproportionate outcomes under capital punishment in a state is positively related to the probability that a senator from that state will oppose permitting exemptions to the death penalty for members of a race that is disproportionately affected.

Crime has been a major political issue over the past several decades. Not surprisingly, the state homicide rate is an important determinant of a state's willingness to enact a capital punishment statute (Nice, 1992). Therefore, it seems reasonable to anticipate that the state homicide rate would also be an important explanatory variable of senatorial voting on capital punishment. Accordingly, it is hypothesized that:

H2. The state homicide rate is positively related to the probability a senator would oppose permitting exemptions to the death penalty for members of a race that is disproportionately affected.

In a democracy the voice of the constituency is supposed to be a prime determinant of the behavior of elected officials. Unfortunately, since surveys contain too few respondents per state for reliable analysis, we cannot directly measure statewide opinion on the death penalty. However, state policy may provide an important guide to state public opinion on the death penalty. While state public policy does not perfectly correspond to state public opinion, there is an impressive degree of congruence in many policy areas (Erikson, Wright, and McIver, 1993). Thus, one potentially important measure of the attitudes of a state's voters on the death penalty should be whether or not a state has adopted death penalty legislation.' Therefore, we hypothesize that:

H3. Senators representing states which have adopted the death penalty are more likely to oppose permitting exemptions to the death penalty for members of a race that is disproportionately affected than are senators from states that have not adopted the death penalty.

While the orientation of the entire state toward the death penalty is likely to effect senatorial behavior, so might the political strength of a sub-set of the legal constituency for whom the particular vote is likely to be of prime importance. Capital punishment is likely to have disproportionate outcomes for African-Americans (GAO, 1990, pp. 5-6). Consequently, racial justice protection should be of critical importance to African-Americans. Therefore, it is hypothesized that:

H4. The percentage of the state's population who are African-American is negatively associated with the probability that a senator will oppose permitting exemptions to the death penalty for members of a race that is disproportionately affected.

Metropolitanization could also effect senatorial voting on capital punishment. However, the direction of the relationship is somewhat difficult to anticipate. As Nice (1992, pp. 1039-1040) suggests, greater metropolitanization would likely breed greater impersonalization. Greater impersonalization, by making residents seem more like "strangers," might produce greater support for tough anti-crime measures such as capital punishment. Moreover, Nice (1992, p. 1043) finds that state metropolitaniza- 
tion is positively associated with the percentage of death row inmates and the execution rate. Conversely, public opinion data seems to indicate that rural areas are more supportive of capital punishment than urban areas (Dike, 1982, p. 63). Since previous research on the impact of metropolitanization on capital punishment is contradictory, we hypothesize that:

H5. The percentage of a state's population living in a metropolitan area is associatcd with the probability that a senator from the same state will oppose permitting exemptions to the death penalty for members of a race that is disproportionately affected, but the direction of the relationship is uncertain.

\section{Political Philosophy of the Senator}

Numerous studies suggest that conservative senators are less supportive of legislation to overcome the effects of racial discrimination than liberals (Clausen, 1973; Schneider, 1979; Smith, 1981; Poole and Daniels, 1985; Poole and Rosenthal, 1991). Therefore, we hypothesize that:

H6. A senator's conservatism is positively rclated to the probability she/he would oppose permitting exemptions to the death penalty for members of a race that is disproportionately affected.

\section{DATA}

The dependent variable in this study is the vote on an amendment by Senator Graham (D-Florida) to strike the racial justice provision of the Omnibus Crime Act of 1991 (S 1241). The racial justice provision would have permitted members of racial minorities to challenge the imposition of the death penalty if capital punishment had been disproportionately applied to their race (Biskupic, 1991). The provision also provided that a state or federal entity could rebut the findings by presenting "clear and convincing" evidence that elements other than race accounted for the disparities in charging and sentencing a prisoner (Biskupic, 1991). The Graham Amendment was adopted 55-41 (Congressional Record 1991, S 8300). A senator who is "announced in favor" of the amendment indicates his or her support for the amendment. Therefore, we count two senators who had announced in favor of the Graham Amendment, but did not vote (DeConcini, D-Arizona and Simpson, R-Wyoming), as supporting the amendment (Congressional Record 1991, S 8300). A "yes" vote was coded as "1," a "no" vote was coded as "0."

It is important to point out that opposition to the Graham Amendment does not appear to be synonymous with opposition to the death penalty per se. Several days after voting on the Graham Amendment, the senate voted on the Hatch/Thurmond Amendment to limit the opportunity of death row inmates to appeal their sentence. Both amendments facilitate carrying out the death penalty. Thus, if a senator's purpose was to oppose the death penalty, they should be expected to oppose both amendments. This is not what occurred. Nine senators who opposed the Graham Amendment supported the Hatch/Thurmond Amendment (Congressional Record, $1991, \mathrm{~S} 8300, \mathrm{~S} 8661$ ). Indeed, there was much inconsistency in voting on the two 
amendments. Seven senators (including Graham) who voted in favor of the Graham Amendment opposed the Hatch/Thurmond Amendment. The gamma between the vote on the Graham Amendment and the Hatch/Thurmond Amendment is only .67. It appears that senators who support the death penalty make important distinctions between the circumstances under which the death penalty should be imposed. Thus, a senator can support the death penalty, but not want it applied in a racially disproportionate manner. Conversely, a senator may not want to set aside the death penalty if it has a racially disproportionate impact, but may want to make it easier to appeal the imposition of the death penalty generally. Therefore, the Graham Amendment would seem to be measuring something other than merely support, or opposition, to the death penalty.

The first independent variable is the degree to which outcomes under the death penalty have a racially disproportionate effect. The essence of proportionality is the ratio of the relative presence of a group in one category to the presence of the same group in another category. For our purposes this would mean the relative size of African-Americans among those adversely effected by the death penalty relative to the size of the African-American population. For example, using the percentage of those adversely effected by the death penalty (e.g., sentenced to death) who are AfricanAmerican would not adjust for the relative size of the African-American population. Thus, if $20 \%$ of those sentenced to murder in a particular state are African-American, this would seem "low" if African-Americans compose $40 \%$ of the state's population, but "high" if African-Americans compose $10 \%$ of the state's population. Therefore, however we measure outcomes under the death penalty, we must divide that percentage by the percentage of the state's population who are African-American.

In the numerator we need to measure the relative impact of the death penalty on African-Americans. The small number of executions (from 1973-1992 there were 191 executions in the United States-data provided by the NAACP Legal Defense and Educational Fund), precludes reliable statistical analysis. Data on arrests for murder do not take into account convictions. Many of those arrested for murder are not convicted of murder. Additionally, since some racial discrimination is likely to occur at the sentencing phase (Baldus, Woodworth, and Pulaski, Jr., 1994), an arrest-based measure is not as valid a measure of racially disproportionate outcomes under the death penalty as is a sentence-based measure. Thus, a sentence-based measure of disproportionate outcomes under capital punishment would include all pre-sentence discrimination. Our primary interest is in the cumulative impact of racially disproportionate outcomes, not the impact of specific steps in this process. Furthermore, data on arrests for murder by race and state are not well-publicized (they are not available from published FBI sources) and thus are not likely to be well-known to senators. Hence, a sentenced-based measure is more likely to be a valid measure of senator's perceptions of disproportionate outcomes than a less-well publicized measure (if one were actually available). This is important because it makes intuitive sense that decision-makers are much more likely to act upon their perceptions of a problem rather than an unknown reality. ${ }^{2}$ The one sentence-based measure of the racially disproportionate impact of the death penalty that is relatively wcll-known, is much more numerous than executions and is available by race and state is the racial composition of those sentenced to death (i.e., the death row population). Accordingly, our measure of racially disproportionate 
outcomes under the death penalty is the percentage of those sentenced to death in a state who are African-American relative to the percentage of the state's population who are African-American. Since individuals in death penalty states with small death row populations could noticeably alter our findings, we re-estimate the results omitting death penalty states with death row populations of 10 or fewer. Data on the racial composition of the death row population was supplied by the NAACP Legal Defense and Educational Fund. The data are as of January 15, $1993 .^{3}$

Typically, legislative scholars have measured senators" political philosophies by using interest group ratings. While Jackson and Kingdon (1992) suggest that using interest group ratings to measure senators' ideologies generally results in overstating the importance of ideology, others have found interest group ratings to be quite valid (Bernstein, 1989, pp. 66, 96; Shaffer, 1989). ${ }^{4}$ We use the ratings of the American Conservative Union (a conservative interest group) to measure ideology instead of the more commonly used ratings of the Americans for Democratic Action (a liberal interest group) for two reasons. First, there are more votes used in the ACU rating and, not surprisingly, more variability. Secondly, unlike ADA, failure to vote does not lower ACU scores. To preclude "vote contamination" (using a vote to predict itself), we use

Table 1. Logit Equation of Senators' Support for Removal of the Racial Justice Provision Pertaining to the Death Penalty

\begin{tabular}{|c|c|c|}
\hline & $\begin{array}{c}\text { All Death } \\
\text { Row Populations }\end{array}$ & $\begin{array}{l}\text { Excluding Death } \\
\text { Penalty States } \\
\text { with Death Row } \\
\text { Populations of } 10 \\
\text { or Fewer }\end{array}$ \\
\hline Intercept & $\begin{array}{l}-2.839^{* *} \\
(1.447)\end{array}$ & $\begin{array}{l}-3.374^{* *} \\
(1.710)\end{array}$ \\
\hline $\begin{array}{l}\text { Degree of } \\
\text { Racially }\end{array}$ & $\begin{array}{l}.346^{* *} \\
(.208)\end{array}$ & $\begin{array}{l}.670^{* *} \\
(.359)\end{array}$ \\
\hline $\begin{array}{l}\text { Disproportionate } \\
\text { Outcomes }\end{array}$ & & \\
\hline Homicide Rate & $\begin{array}{l}.546^{* * *} \\
(.209)\end{array}$ & $\begin{array}{l}.518^{* *} \\
(.251)\end{array}$ \\
\hline Death Penalty & 1.315 & -.822 \\
\hline Dummy Variable & $(1.064)$ & $(1.818)$ \\
\hline African-American & -.070 & .016 \\
\hline Population & $(.071)$ & $(.089)$ \\
\hline Metropolitanization & $\begin{array}{l}-.063^{*+*} \\
(.025)\end{array}$ & $\begin{array}{l}-.060^{* *} \\
(.029)\end{array}$ \\
\hline $\begin{array}{l}\text { Conservatism of } \\
\text { the Senator }\end{array}$ & $\begin{array}{l}.081^{* * * *} \\
(.019)\end{array}$ & $\begin{array}{l}.085^{* * * *} \\
(.022)\end{array}$ \\
\hline $\begin{array}{l}\text { Likelihood } \\
\text { Ratio Index }\end{array}$ & .60 & .68 \\
\hline $\begin{array}{l}\text { Number of } \\
\text { Observations }\end{array}$ & 96 & 78 \\
\hline
\end{tabular}

Notes: Estimated standard errors are shown in parentheses. ${ }^{*} p \leq$ one-tailed $.10^{* *} p \leq$ one-tailed $.05 ;{ }^{* *} p \leq$ one-tailed $.01 ;{ }^{* * *} p \leq$ one-tailed .001 . 
1992 ACU scores to predict a 1991 vote. Scores range from 0\% (least conservative) to $100 \%$ (most conservative). The scores were supplied by the American Conservative Union.

The death penalty dummy variable was taken from data supplied by the NAACP Legal Defense and Education Fund. States having death penalty statutes were coded "1," while states not having death penalty statutes were coded " 0 ." The state homicide rate was taken from the Sourcebook of Criminal Justice Statistics. The percentage of the state's population who are African-American and the percentage of the state's population living in a metropolitan area were taken from the Statistical Abstract of the United States.

\section{FINDINGS}

The results of a logit analysis of the basic model are presented in Table 1.

Table 2. Logit Equation of Senators' Support for Removal of the Racial Justice Provision Pertaining to the Death Penalty Controlling for African-American Education and Income (All Death Row Populations)

\begin{tabular}{|c|c|c|c|c|}
\hline Intercept & $\begin{array}{c}4.063 \\
(4.539)\end{array}$ & $\begin{array}{l}-1.282 \\
(4.241)\end{array}$ & $\begin{array}{c}1.208 \\
(3.710)\end{array}$ & $\begin{array}{l}-5.547 \\
(4.562)\end{array}$ \\
\hline Degree of & $.397^{*}$ & $.370^{* *}$ & $.560^{* *}$ & $.3 .37^{*}$ \\
\hline Racially & $(.241)$ & $(.217)$ & $(.270)$ & $(.211)$ \\
\hline \multicolumn{5}{|l|}{ Disproportionate } \\
\hline \multicolumn{5}{|l|}{ Outcomes } \\
\hline \multirow[t]{2}{*}{ Homicide Rate } & $.604^{* * *}$ & $.538 * * * *$ & $.499^{* *}$ & $.594 * * * *$ \\
\hline & $(.255)$ & $(.209)$ & $(.227)$ & $(.230)$ \\
\hline Death Penalty & .762 & 1.263 & -.690 & $1.492^{*}$ \\
\hline Dummy Variable & $(1.388)$ & $(1.067)$ & $(1.517)$ & $(1.104)$ \\
\hline African-American & $-.207^{*}$ & -.079 & -.059 & -.071 \\
\hline Population & $(.135)$ & $(.075)$ & $(.074)$ & .071 \\
\hline \multirow[t]{2}{*}{ Metropolitanization } & $-.044^{*}$ & $-.061 * * * *$ & -.041 & $-.082^{* * *}$ \\
\hline & $(.030)$ & $(.025)$ & $(.033)$ & $(.041)$ \\
\hline Conservatism of & $.092^{* * * *}$ & $.082^{* * * *}$ & $.084^{* * * *}$ & $.082^{* * * *}$ \\
\hline the Senator & $(.024)$ & $(.019)$ & $(.022)$ & $(.019)$ \\
\hline Male African- & $-.128^{*}$ & & & \\
\hline American Education & $(.086)$ & & & \\
\hline \multirow{2}{*}{ Population Education } & & -.024 & & \\
\hline & & $(.062)$ & & \\
\hline Male African- & & & -.534 & \\
\hline American Income & & & $(.522)$ & \\
\hline \multirow[t]{2}{*}{ Population Income } & & & & .181 \\
\hline & & & & $(.287)$ \\
\hline Likelihood & .61 & .61 & .60 & .61 \\
\hline Ratio Index & & & & \\
\hline Number of & 74 & 96 & 74 & 96 \\
\hline Observations & & & & \\
\hline
\end{tabular}


Table 3. Logit Equation of Senators' Support for Removal of the Racial Justice Provision Pertaining to the Death Penalty Controlling for African-American Education and Income ([xcluding Death Row Populations of 10 , or Fewer)

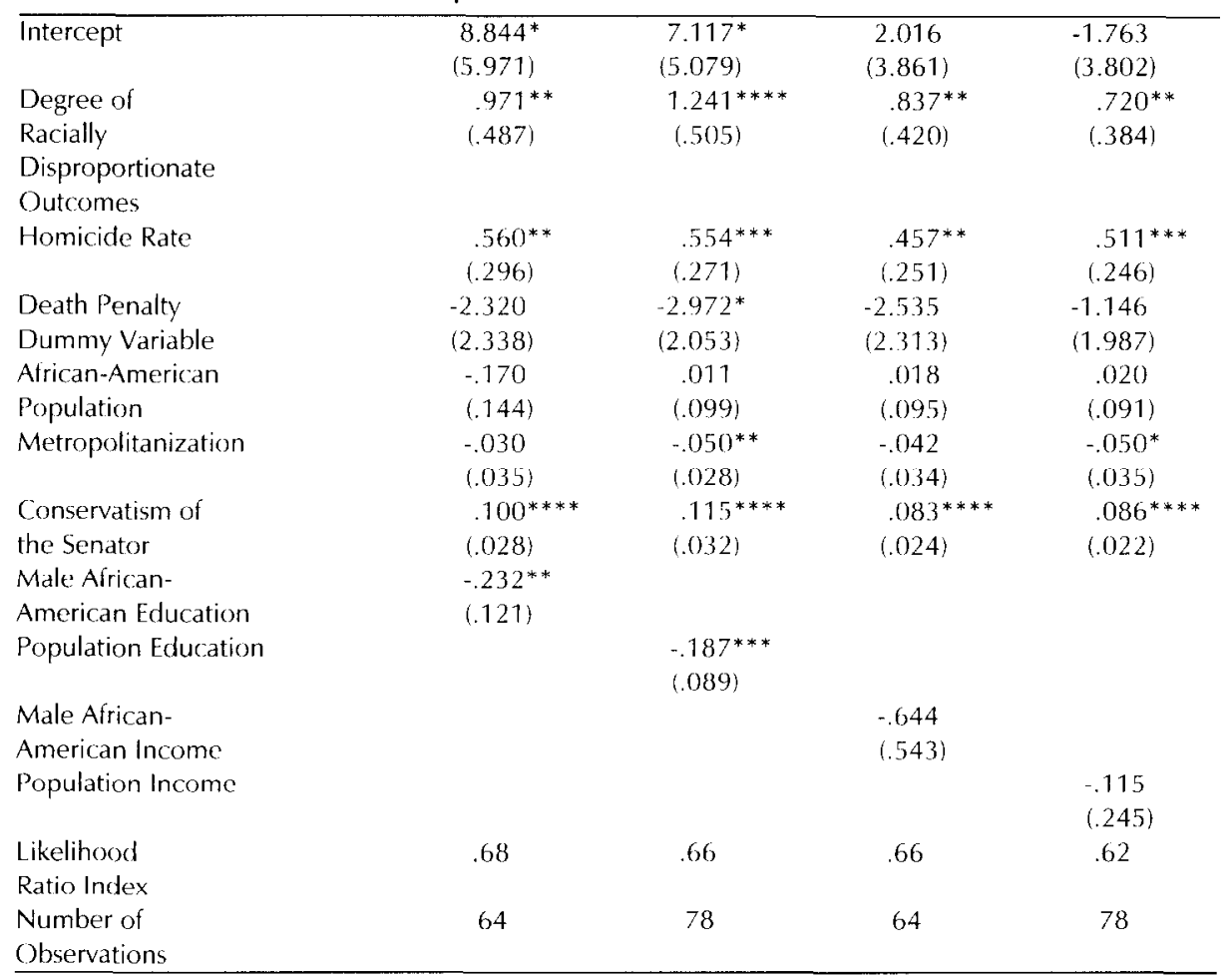

Notes: [stimated standard errors are shown in parentheses. ${ }^{*} p<$ one-tailed $.10{ }^{* *} p<$ one-tailed $.05 ;^{* * *} p<$ one-tailed $.01 ;^{* * * *} p<$ one-tailed 001 .

\section{Constituency Characteristics}

The results in Table 1 show some support for the five hypotheses concerning constituency characteristics. The degree of racially disproportionate outcomes under capital punishment is positively signed (as hypothesized) and statistically significant. This result strongly suggests that racially disproportionate effects under capital punishment increases the opposition of senators' to support the racial justice provision.

One could argue that both our measure of racially disproportionate outcomes under capital punishment does not account for variation in the propensity of African-Americans to commit murder across states. If the ratio of disproportionate outcomes under capital punishment vary between two states this could be a function of a different propensity to commit murder within the African-American communities across the two states. This possibility was taken into account when we controlled for the homicide rate in Table 1 . However, since the homicide rate is not disaggregated by race, it might be argued that it is necessary to include controls that are disaggegated by race 
and that isolate factors highly likely to be related to the incidence of homicide. Like all Americans, the propensity of African-Americans to commit homicide is likely to be highly related to education or income. As over $98 \%$ of the death row population is male (NAACP Legal and Educational Fund, 1993), we will separately control for the percentage of African-American males age 25 or older, who graduated from high school, as well as median African-American male income (in thousands of dollars).

Unfortunately, because the African-American population in eleven states is too small for reliable estimation of African-American male education and income, we can only replicate the model in Table 1 for 39 states. Accordingly, we re-estimated the model in Table 1 (including African-American male education or income). ${ }^{5}$ The empirical results appear in Table 2, columns 1 and 3 (all death row populations) and in Table 3, columns 1 and 3 (excluding death row populations of 10 , or fewer).

Since a larger number of observations would increase the confidence and consistency of our previous statistical results we would like to find proxies for AfricanAmerican male education and income that are available for all 50 states. An obvious approach would be to use education and income for the total population rather than the African-American male population. The measures for the entire population are highly correlated with the measures for the $\Lambda$ frican-American male population (education .92; median income .75). The empirical results using population education or income might be thought of as reasonable estimates for what empirical results would have been if reliable data by race were available for all 50 states. These results are reported in Tables 2 and 3, columns 2 and 4 .

The results from Tables 2 and 3 show that the impact of racially disproportionate outcomes on the likelihood that a senator will support the racial justice provision is not only robust across different model specifications, but is typically stronger when African-American male education or income, or population education or income, are held constant.

Regardless of model specification, the results in Tables 1-3 indicate that the higher the homicide rate in their state, the more likely the senator is to oppose permitting the death penalty to be set aside because of racially disproportionate outcomes. The result is statistically significant. Additionally, senators from states which have adopted the death penalty are more likely to oppose setting aside the death penalty because of racially disproportionate outcomes. However, the results are not statistically significant. While the coefficient for African-American population is signed as hypothesized, the results are not close to achieving statistical significance. ${ }^{6}$ Consistent with Dike's (1982) results, metropolitanization is negatively signed and statistically significant. Tables 2 and 3 indicate that the results for the homicide rate, the death penalty dummy variable, percent of the population who are African-American and metropolitanization do not appear particularly sensitive to model specification.

\section{Political Philosophy of the Senator}

The results in Tables 1-3 provide very strong support for the hypothesis that conservatism of the senator is positively related to the probability that she/he will favor removing the racial justice protection with respect to capital punishment. The coefficients are always highly statistically significant. 
We can asses the "goodness of fit" of the model by the likelihood ratio index (Greene 1993, pp. 651-653). As the likelihood ratio index is more conservative than $\mathrm{R}^{2}$, the approximately .60 scores in Tables $1-3$ indicate a reasonably good fit. ${ }^{7}$

\section{IMPLICATIONS}

From the standpoint of the congressional behavior literature, the results have important similarities and differences with previous research. As is often the case, political ideology is the most important predictor of senators' voting behavior (Bernstein, 1989; Poole and Daniels, 1985; Poole and Rosenthal, 1991). Additionally, unlike some of the congressional literature (Bernstein, 1989), we find constituency opinion both signed as hypothesized and statistically significant. ${ }^{8}$

Our results also contain similarities and differences with Nice's (1992) study of the adoption and implementation of state capital punishment statutes. Like Nice (1992), we find that the homicide rate is positively associated with a more pro-capital punishment outcome. However, unlike Nice (1992), we find that metropolitanization is negatively associated with senatorial support for capital punishment.

From the perspective of civil rights advocates, the findings of this study are both important and sobering. The confirmation vote on Supreme Court Justice Clarence Thomas revealed that African-American electoral strength can strongly influence senators who are running for re-election, heavily dependent upon African-American voters and have neither strong countervailing personal philosophical or constituent pressures (Overby, Henschen, Strauss, and Walsh, 1992). This research more demonstrates the limitations of African-American political influence. After controlling for all other predictor variables, racially disproportionate outcomes under capital punishment are positively associated with political support for eliminating racial justice protections. While this result is only significant at the .05 level using a one-tailed test, it is still strong and suggestive. The greater the racially disproportionate effects of policy, the less likely policymakers are to remove the racially disproportionate effects of the policy. Obviously, the results provide no support for the hope of civil rights advocates that the greater the racially disproportionate outcomes under a policy, the more likely the policy will either be changed or removed. Just as the relative size of the AfricanAmerican population was generally inversely related to the speed of adoption of state civil rights laws, disproportionate outcomes under capital punishment are inversely related to support for eliminating disproportionate outcomes. The greater the cost of removing the racially disproportionate effects of a policy, the less likely the political support to do so.

Our findings suggest a policy context similar to the civil rights movement of the 1960s. In political environnents where support for African-American civil rights conflicted with majority public opinion, pro-civil rights political activity often had negative direct effects, but positive indirect effects. Thus, activating a constituency deprived of civil rights often harmed the civil rights movement in the immediate area. The benefit of political activity was often to appeal to the consciences of the mass, or the political elite (Dye 1992, pp. 47-80), in locales less affected by discrimination. The eventual elimination of discrimination came from such minimally affected areas having a majority of the voting strength. While we are examining disproportionate 
outcomes and not discrimination, the parallels are important. However, since few areas are minimally affected by crime, civil rights forces are likely to face difficulty in removing the racially disproportionate effects of anti-crime policy.

Acknowledgment: The authors wish to thank Chrisopher Achen, David Baldus, Gary King and Kenneth J. Meier for their advice on this revision.

\section{NOTES}

1. In the analysis that appears ahead, we tried several alternative measures of public opinion: the mean ideology of the state's voters (Erikson, Wright, and McIver, 1993, p. 16); the ideology of the senator's electoral constituency (members of the senator's party plus independents-adapted from Erikson, Wright and McIver 1993, p. 40); the percentage of the statewide vote for Dukakis in 1988; the percentage of the state's population who are 25 years of age, or older, who have at least a bachelor's degree; and, state median family income. None of these measures approached statistical significance.

2. The authors would like to thank David Baldus for this idea.

3. One possible alternative measure of racially disproportionate outcomes under the death penalty is the number of times that a claim of race discrimination was raised in a given state supreme court (prior to McCleskey v. Kemp). Such a measure would raise serious validity questions. The number of times that a claim of racial discrimination is raised is greatly influenced by the availability of legal aid and the financial resources necessary to prove racial discrimination. States vary noticeably in their willingness to provide such resources. The authors would like to thank David Baldus for this insight.

4. Jackson and Kingdon (1992) argue that interest group ratings should not be used to measure legislators' political philosophies. They suggest that the roll call votes used by interest groups are drawn from the same belief structure as the vote we are trying to predict. Thus, interest group ratings are not an independent measure of ideology. While this may be true, we should expect it. As senators are highly likely to have well-developed philosophies, and hence, policy preferences, we should, for example, expect Helms and Kennedy to vote very differently. The authors would like to thank Keith T. Poole for his advice on this point. The important consideration is how accurately the interest group rating will estimate either the strength and/or the magnitude of the impact of ideology on legislators' voting decisions. Snyder (1992, pp. 332-333) indicates that rather than over-estimating the impact of ideology, as Jackson and Kingdon (1992) suggest, the S-shaped distribution of interest group rating scores actually causes them to under-estimate the impact of ideology.

Following Snyder (1992, p. 341) we also used the Poole and Rosenthal (1991) measure of ideology. For the latest year available (1989) their "dominant" dimension correlated with the $1989 \mathrm{ACU}$ measure at .96. Thus choice of an indicator makes little difference.

5. Since the purpose of including African-American education and income variables is to control for the propensity to commit murder, these variables should he measured as close as possible to the time of the crime. For 1993, the mean years a death row inmate had spent on death row was 9.4 years (Bureau of Justice Statistics Bulletin, Table 12, December, 1994). Allowing a minimum of 2 years for all pre-death row stages (i.e., apprehension, pretrial, trial and sentencing), suggests that the shortest plausible mean time between the commission of a murder and execution would be 11.4 years $(9.4$ years on death row plus 2 years for all pre-death row stages). Subtracting this 11.4 year mean from January, 1993, (the date of the death row population data) leaves late 1981 as the probable mean year for the commission of a murder for which a 1993 death row inmate was convicted. Since 1981 
is closer to 1980 than to 1990,1980 census data is more appropriate. Accordingly, this study uses 1980 African-American male education and income data. This data was taken from the U.S. Census of Population: General Social and Economic Characteristics. Data on the education and income of the entire population was taken from the State and Metropolitan Area Data Book.

6. Multicollinearity is potentially a problem. The $\mathrm{R}^{2}$ from regressing percent of the population who are African-American on all other independent variables in Table 1 is .61. While this is not extremely high, it might be cause for some concern. An additional possibility is that the equation is mis-specified. One could argue that the election constituency is different than the legal constituency (Fenno 1978).

7. The proportional reduction in error when using the model in column 1 of Table 1 , as opposed to a "naive" model, is approximately $76.2 \%$. The "naive" model consists of only a constant term. Using a .5 cutoff point (i.e., if the probability of a particular senator voting "yes" was .5, or greater, they were predicted to vote "yes"), the "naive" model correctly predicts $58 \%$ of the cases whereas the full model (as presented in Table 1) correctly predicts $90 \%$. This is a proportion reduction in error of approximately $76.2 \%$ [ $1-(100 \%-90 \%)$ $100 \%-58 \%)=76.19]$.

8. It should be noted, however, that our measure of constituency opinion is policy and not a direct measure of constituent attitudes. Attitudinal measures of constituency opinion were insignificant (see note 1).

\section{REFERENCES}

Baldus, D. C., G. Woodworth, and C. A. Pulaski, Jr. (1994). Reflections on the Inevitability of Racial Discrimination in Capital Sentencing and the Impossibility of its Prevention, Detection, and Correction. Washington and Lee Law Review, 5I(2): 359-430.

Bernstein, R. A. (1989). Elections, Representation, and Congressional Voting Behavior. Englcwood Cliffs: Prentice Hall.

Biskupic, J. (1991). Senate Begins Annual Ritual of Toughening Crime Law. Congressional Quarterly Weekly Report, 49(25): 1665-1669.

Bureau of Justice Statistics. (1994). Capital Punishment. NCJ-150042. Washington, DC: U.S. Government Printing Office.

Clausen, A. (1973). How Congressmen Decide: A Policy Focus. New York: St. Martins. Congressional Record. (1991). Washington, DC: U. S. Government Printing Office.

Dike, S. (1982). Capital Punishment in the United States. Hackensack, NJ: National Council on Crime and Delinquency.

Dye, T. R. (1992). Understanding Public Policy, 7th edition. Englewood Cliffs: Prentice Hall.

Erikson, R. S., G. C. Wright, and J. P. McIver. (1993). Statehouse Democracy: Public Opinion and Policy in the American States. Cambridge: Cambridge University Press.

Fenno, R., Jr. (1978). Home Style: House Members in Their Districts. Boston: Little Brown.

General Accounting Office. (1990). Racial Disparities in Sentencing. GAO/GGD-90-57. Washington, DC: U. S. Government Printing Office.

Greene, W. H. (1993). Econometric Analysis, 2nd edition. New York: Macmillian Publishing Company.

Jackson, J. E. and J. W. Kingdon. (1992). Ideology, Interest Group Scores, and Legislative Votes. American Journal of Political Science 36( 3): 805-823.

Nice,D.C.(1992). The States and the Death Penalty. Western Political Quarterly, 45(4): 1037-1048.

Overby, L. M., B. M. Henschen, J. Strauss, and M. H. Walsh. (1992). Courting Constituents? An Analysis of the Senate Confirmation Vote on Justice Clarence Thomas. American Political Science Review, 86(4): 997-1003. 
Poole, K. T. and R. S. Daniels. (1985). Ideology, Party, and Voting in the U.S. Congress, 1959 1980. American Political Science Review, 79 ( 2): 373-399.

Poole, K. T. and H. Rosenthal. (1991). Patterns of Congressional Voting. American Journal of Political Science, 35(1): 228 278.

Schneider, J. (1979). Ideological Coalitions in Congress. Westport: Greenwood Press.

Shaffer, W. R. (1989). Rating the Performance of the ADA in the U.S. Congress. Western Political Quarterly, 42(1): 33-51.

Smith, S. S. (1981). The Consistency and Ideological Structure of U.S. Senate Voting Alignments, 1957-1976. American Journal of Political Science, 25(4): 780-795.

Snyder, J. M., Jr. (1992). Artificial Extremism In Interest Group Ratings. Legislative Studies Quarterly, 17(3): 319-345.

State and Metropolitan Area Data Book. (1986). Washington, DC: U.S. Government Printing Office.

Sourcebook of Criminal .Justice Statistics. (1991). Washington, DC: U.S. Government Printing Office.

Statistical Abstract of the United States. (1992). Washington, DC: U.S. Government Printing Office.

U.S. Census of Population: General Social and Economic Characteristics by State. (1983). Washington, DC: U.S. Government Printing Office. 